\title{
REVIEW ESSAY: Winning Freedoms
}

\author{
Hannana Siddiqui
}

Letter to Christendom Rana Kabbani Virago: London, 1989, $£ 3.99$ Pbk, ISBN $185381119 \mathrm{X}$

When I was to start secondary school, my father and I went in search of a school uniform. A blazer and blouse were easy to find, and I was particularly pleased that the skirts were abundantly available. As a Muslim, my father had forbidden me to wear skirts or expose my legs in any way. I thought that with the coming of school uniform, even my father could not escape the requirements of the British school system. I thought that for the first time in my life, I was about to wear a skirt.

However, when the shop assistant produced one, I was shocked to hear my father ask for a pair of trousers instead. The assistant, a little taken aback by this request, said she was unable to assist us. We went to many shops in order to purchase a suitable pair of trousers. As we wandered from store to store, I prayed. One minute my prayers were addressed to 'God' (in the Christian sense) and another minute, they were addressed to 'Allah'. I was praying that my father would be unable to find a suitable pair of trousers and be forced to buy a skirt instead. Unfortunately, my prayers were not answered by either God or Allah, and I was compelled to wear trousers to school.

I was disappointed. It set me apart once again from the white children. It was another aspect of my difference, which prevented me from fitting in. It also represented another defeat for me - that on the home front. I had always wanted to wear a skirt, simply because I wanted the choice and I felt stifled by the restrictions imposed on me by my family and our cultural and religious background.

I believed that 'God' or 'Allah' were one and the same thing. They presented no contradictions for me. I imagined them to be merciful, compassionate, imposing no cruel restrictions or dictates on me or others. Yet, my father's interpretation was very different from mine. He was horrified whenever I mentioned Christianity or questioned Islam. In the process of growing up, my views underwent many changes. I 
questioned my whole belief in God and Allah, especially as these beliefs began to throw up contradictions. I realized that my interpretation meant very little in everyday reality. In the name of my religion and culture, I was told that not only was I required to cover my legs, but I was also required to get married to a partner chosen for me by my family. Then I was expected to have children and, if I had an education, the use I made of it depended on my husband. Furthermore, as a good Muslim mother, I was also expected to pass on these traditions to my children in order to preserve my religion and culture. These precepts were laid down for me not only by my father, but also by the whole extended family and the community to which I belonged. I was isolated. I stopped praying to God or Allah, and when I refused to 'fit in', I was castigated and rejected.

My parents were labelled 'failures'. They were accused of not cocooning me from the corrupting influence of school and television, for having let me become 'Westernized'. They felt dishonoured and hurt. My stomach churned with dilemmas. I did not want to offend and cause pain, but I had to criticize and question because I found it hard to accept what was required of me.

At the same time, I was battling with my teachers and schoolfriends. I no longer wanted to fit in their world either. It did not matter if I was different because I wore a pair of trousers. I refused to accept the rules laid out for me by this wider society and its host culture. Instead, I punched against them, in street fights with white youth and in classroom lessons on Eurocentric history, literature and religious education.

I no longer wanted to be told whether I could wear a skirt or a pair of trousers. I wanted to make the choices myself and forge my own identity. Later, I was to recognize these battles as antiracist and feminist struggles.

It is because of these struggles that I do not believe that Rana Kabbani, in her book Letter to Christendom, can afford to dismiss Salman Rushdie's novel, The Satanic Verses, as being 'no longer accountable' to its non-Western readership, and politically irresponsible by its 'frivolous mockery' of Islam. She attemps to invalidate Rushdie's criticism of Islam by equating it with his need to perpetuate his success as a writer by satisfying Western literary values and Western sensibilities, thereby becoming depoliticized and forced into compromise. She goes on to argue that:

Success presupposes (or rewards) rejection of one's roots. Rushdie's (perhaps unwitting) decision in The Satanic Verses to recant a political project that he had been identified with, to go back on what he stood for, seems to me an unfortunate consequence of his success, which may have led him to feel that he is no longer accountable to his non-Western readership. 
achieve what Midnight's Children had been so successful in doing. As a pioneering work, she argues, the latter novel resulted in the 'advance of cultural accommodation' because it appealed to both the Western and non-Western readership. It reflected the 'complicated political reality to which I belong'. The Satanic Verses, however, she states, far from following the tradition of satirical writing in Islam, in its tone of mockery, added dramatically 'to the clash of cultures, to a confrontationalism at once self-defeating and damaging'. Rana Kabbani concludes that The Satanic Verses set back the cause of antiracism.

It is both extremely cynical and simplistic to argue that Rushdie's ambitions as a writer created a depoliticization of his writing and represents a compromise to Western sensibilities. To argue that he may have done this unwittingly is simply patronizing. The Satanic Verses, far from being depoliticized, is as charged with politics as the reaction it created - with the politics of race and religion: of Western racism and the orthodoxies of Islam. The book echoes an exploration and questioning of religious values for those of us who have been involved in this process all our lives. It also follows Rushdie's tradition of addressing racism. Therefore, it reflects the complicated political reality to which $I$ belong. To dismiss and classify my views as a 'Westernized, Muslim intellectual' response is to deny my experiences, which have included fighting both racism and the orthodoxies of my religious and cultural background. It also denies the experiences of many ordinary Asians living in Britain, especially women, who have been castigated and censored for expressing doubt and dissent within their families and communities. It neglects the feminist struggles of Asian women across the world, who have been fighting against the imposition of religious values in their lives. These cannot be simply invalidated and dismissed as a result of too much 'Westernization', wittingly or unwittingly absorbed.

Rana Kabbani, as a feminist, recognizes, of course, that there are aspects of Islam which are oppressive to women, but so are, she argues, aspects of Christianity and Judaism, which are both patriarchal religions. I would go further and argue that all religions are oppressive to women; they regard women as inferior, subject to the control of male members of the family. Interpretations do vary, but as the rise of religious fundamentalism on an international scale tightens its grip, demanding greater conformity to traditional orthodoxies, it has become harder to practice a more liberal version of religion. Furthermore, since Rana Kabbani identifies her feminism in religious terms, as part of the 'Muslim Sisterhood', her vision of liberation is compromised by the very religion that she accepts is oppressive. She argues however that there are aspects of Islamic tradition which are positive, such as arranged marriages and the wearing of the hijab.

Rana Kabbani justifies arranged marriages on the grounds that 'A Muslim girl cannot be forced to marry against her wishes, although there can be strong pressures, varying from family to family and often 
the result of economic difficulties'. She severely underestimates not only the effect of family pressure, but the whole religious, moral and cultural framework within which women live their daily lives, having little or no power both in the home and outside of it. The concept of izzat (honour) the fear of causing shame, and the threat of violence silence many women into compliance. The fear of being rejected and isolated from their own communities, coupled with the added problems of racism, deny many women the right to make their own choices. Rana Kabbani neglects the fact that arranged marriages are a form of control over women's sexuality, where they have limited choice of who and when they marry, and no choice of whether to marry at all! Similarly, Rana Kabbani assumes that the hijab protects women from being regarded as sexual objects. This may be so, but surely the choice of whether to wear a hijab or not should be left with women themselves. Many women fear the imposition of the hijab precisely because it denies their sexuality and is part and parcel of a wider process of male control. For many women, the question is not simply about picking and choosing which part of Islam they wish to conform to, but a question of risking ostracization if they do not obey Islam in its entirety.

Rana Kabbani attempts to marginalize the experiences of women who refuse to submit, or are forced to have arranged marriage or conform to a dress code. Choices are even more limited for working-class women, who (unlike Rana Kabbani) are less likely to have the resources to opt out and escape from pressures to conform.

In my experience as a worker at Southall Black Sisters, I have come across many Muslim women and girls who feel that they are forced to marry against their wishes. Rana Kabbani cannot give blanket assurances to these women and girls that they can refuse to marry without facing repurcussions from their families and communities. Although a feminist, Rana Kabbani offers no hope for these women.

Rana Kabbani also argues that the hijab has become a symbol of resistance from the imperialist, racist, and Christian forces of the West, which demand assimilation, and overpower and destory Eastern cultures. I accept that this perspective exists, even in Britain, where, after the Rushdie affair, some women are reasserting their Muslim identity by taking up the hijab, but I believe that such a perspective mitigates against the long-term interests of women. It poses dangers for those of us who have been working to liberate ourselves from these restrictions. These developments have to be seen in the context of wider pressures to control women. For example, the demand for separate religious schools, especially for girls, is a serious setback, because it will lead to indoctrination and pressure to return to the traditional role for a Muslim woman, that of mother and wife.

Feminists who uphold these demands are prepared to sacrifice countless women and girls to the cause of antiracism. Such a position can only be retrogressive because it makes alliances with the forces of patriarchy, conservatism and fundamentalism within our communities. 


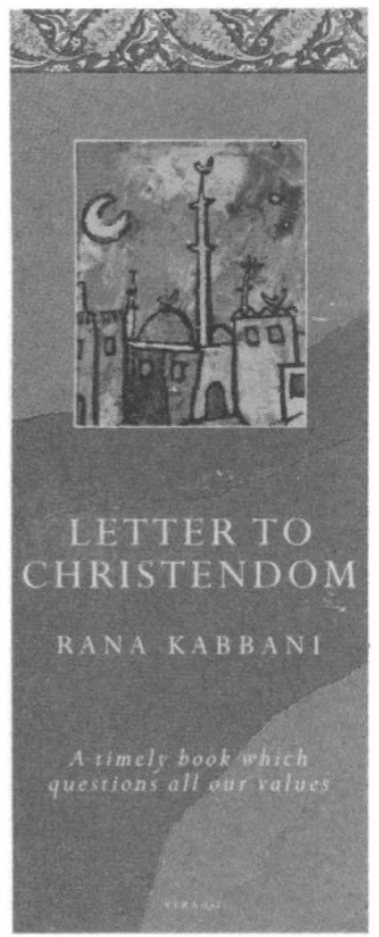

Such alliances do not strengthen the antiracist movement but, rather, weaken it because they fail to incorporate other equally important struggles, by demanding equality for all within their communities.

The failures of the antiracist left, and of progressive movements generally, have allowed the space for a new identity based along religious lines to be created, an identity which threatens the radical secular notion of uniting as black or even as Asians against racism. Instead, a religious identity divides us, demanding segregation into religious schools and forcing minority groups to compete for power and resources instead of uniting in the face of common enemies.

Religous fundamentalism appeals to the most reactionary views and perspectives. Frightened by the corrupting influence of the West, conservative forces demand control over women within their own communities. These forces justify their actions on the assumption that they are the guardians of culture and tradition. Whilst some women

have accepted a new Muslim identity and thrown in their lot behind fundamentalists, there are those of us who continue to resist.

Women Against Fundamentalism is comprised of women from all religious and cultural backgrounds, and aims to give a coherent voice to this resistance. In other literature, Rana Kabbani has been critical of Women Against Fundamentalism, declaring it to be the political equivalent of The Satanic Verses, and dismissing its efforts to improve the lives of women by categorizing it as part of the 'Western' response, contributing to the racist backlash. Yet Rana Kabbani herself offers no concrete help to women faced with the oppressive aspects of Islam or those of any other religion. Rather, she prefers to retain some traditions which trap women in submissive roles. She also prefers to silence Women Against Fundamentalism by attempting to de-legitimize our criticisms, classifying our views as a 'westernized... intellectual' response. Here she is playing on Western guilt and Eastern scorn.

Rana Kabbani encourages a united approach to racism and imperialism. Such an approach, however, constructs a monolithic image of the Muslim or Asian community, a view accepted by multiculturalists, many antiracists and conservative male leaders alike. Such a perspective hides the divisions of gender and class that exist within our communities. Rana Kabbani and her like fail to recognize that different sections of the community have different interests. The interests of women, and other less powerful sections, are often not represented. By adhering to her united front approach, based not on principles of 
equality, but on the need to preserve a strictly defined religious culture, she defends a set of élitist, and class-bound interests. She attempts to marginalize opposition to Islam and offers no real challenge to the inequalities that exist both within and outside our communities. Although she accepts that criticism of Islam is permissible, she also defines the parameters of acceptability of such criticism. This is an arbitrary and subjective exercise, imposing censorship and restraining freedom of speech and action.

For her, it is not possible to be both Western and non-Western. She states that she knows which side she is on, and that the Rushdie affair helped her clarify this and reassert her identity as a Muslim. This contradicts her original premise that she was writing the book to reach a personal accommodation between the two cultures. She has also failed to recognize that she has utilized the West to the full by her Cambridge education, and has lived a life of relative ease in Syria by her connexions with the wealthy and powerful in the East. She herself is a product of both worlds and has access to considerable freedoms in each. However, she seems to want to deny the same freedoms to women who face the brunt of both racism and oppression in the home. Rana Kabbani betrays little or no knowledge of women, often from poor backgrounds, who have neither the power or the means to escape restrictions. By arguing in such terms, she is, in effect, denying the right of women to determine their own lives.

I believe that it is possible to reach a point of balance between two cultures, to forge an identity that is not based on the restriction of freedom of others. This is the result of the lessons I have learned in my small struggles at home and school. I have learnt that it is not a simple either/or situation. In fact, my struggles have created a stronger bond between myself and my family, who have grown to respect my right to choose for myself.

I realize that enemies exist on both sides of the cultural and racial divide, as do friends. Winning freedoms means the right to choose who my enemies and friends are. In this the hope for the future lies.

\section{Note}

Hannana Siddiqui is a member of Southall Black Sisters and of Women Against Fundamentalism.

I have won enough freedoms to choose if I wear a shirt today or a pair of trousers tomorrow. 